\title{
Relation between Exercise Performance and Blood Storage Condition and Storage Time in Autologous Blood Doping
}

\author{
Benedikt Seeger and Marijke Grau *
}

Citation: Seeger, B.; Grau, M Relation between Exercise Performance and Blood Storage Condition and Storage Time in Autologous Blood Doping. Biology 2021, 10, 14. https://doi.org/ 10.3390/biology10010014

Received: 15 November 2020 Accepted: 25 December 2020 Published: 29 December 2020

Publisher's Note: MDPI stays neutral with regard to jurisdictional claims in published maps and institutional affiliations.

Copyright: (C) 2020 by the authors. Licensee MDPI, Basel, Switzerland. This article is an open access article distributed under the terms and conditions of the Creative Commons Attribution (CC BY) license (https: / / creativecommons.org / licenses/by/4.0/).
Molecular and Cellular Sports Medicine, German Sport University Cologne, 50677 Cologne, Germany; benediktseeger@web.de

* Correspondence: m.grau@dshs-koeln.de; Tel.: +49-221-4982-6116

Simple Summary: Autologous blood doping (ABD) refers to sampling, storage, and re-infusion of one's own blood to improve circulating red blood cell (RBC) mass and thus the oxygen transport and finally the performance capacity. This illegal technique employed by some athletes is still difficult to detect. Hence knowledge of the main effects of ABD is needed to develop valid detection methods. Performance enhancement related to ABD seems to be well documented in the literature, but applied study designs might affect the outcome that was analyzed herein. The majority of recent studies investigated the effect of cold blood storage at $4{ }^{\circ} \mathrm{C}$, and only few studies focused on cryopreservation, although it might be suspected that cryopreservation is above all applied in sport. The storage duration — the time between blood sampling and re-infusion-varied in the reported literature. In most studies, storage duration might be too short to fully restore the RBC mass. It is thus concluded that most reported studies did not display common practice and that the reported performance outcome might be affected by these two variables. Thus, knowledge of the real effects of $\mathrm{ABD}$, as applied in sport, on performance and associated parameters are needed to develop reliable detection techniques.

Abstract: Professional athletes are expected to continuously improve their performance, and some might also use illegal methods—e.g., autologous blood doping (ABD)—-to achieve improvements. This article applies a systematic literature review to investigate differences in the ABD methods and the related performance and blood parameters owing to different storage conditionscryopreservation (CP) and cold storage (CS) - and different storage durations. The literature research resulted in 34 original articles. The majority of currently published studies employed CS during ABD. This contrasts to the applied storage technique in professional sports, which was mainly reported to be CP. The second outcome of the literature research revealed large differences in the storage durations applied, which were in the range of one day to 17 weeks between blood sampling and re-infusion, which might affect recovery of the red blood cell mass and thus performance outcome related to ABD. Data revealed that performance parameters were positively affected by ABD when a minimal storage duration of four weeks was adhered. This article identified a need for further research that reflect common $\mathrm{ABD}$ practice and its real effects on performance parameters, but also on related blood parameters in order to develop valid and reliable ABD detection methods.

Keywords: autologous blood doping; exercise performance; storage conditions; storage duration; red blood cells

\section{Introduction}

International world class athletes are expected to continuously improve their performances [1,2] and some athletes not only use legal but also illegal methods to achieve this improvement $[2,3]$. Autologous blood doping (ABD) appears to be a widely applied illegal method to enhance an athlete's performance [4,5]. The reason why ABD represents a preferred method might be due to the finding that the muscular oxygen $\left(\mathrm{O}_{2}\right)$ supplying 
system is a major limiting factor in endurance sports [6] and ABD is able to increase this system without being detectable so far $[7,8]$. This assumption is further supported by the recent disclosures and the ongoing doping investigation and trial in Germany referred to as "Operation Aderlass" $[9,10]$. However, since doping does not only harm the sport's reputation [11], but also possibly the athlete's health [12,13], it is important to develop a reliable and valid $\mathrm{ABD}$ detection method. This systematic review aims to analyze published protocols of applied ABD techniques and the related effects on tested performance parameters in order to evaluate the effectiveness of the methods applied, especially related to changes of the in vivo red blood cell (RBC) system, and to compare the applied methods with actual doping practice. This knowledge will be needed to assess the real effects of published ABD-related protocols in order to understand the related changes in the RBC system necessary for the development of ABD detection methods.

The ABD procedure consists of three major steps: (1) the blood sampling from a subject, (2) the processing and storage of the blood or blood components, and (3) the re-transfusion of whole blood or a red blood cell (RBC) concentrate to the initial donor [4]. Each of these steps can be implemented with some variations, which in turn might affect the effect size of ABD [4]. First, the donated blood volume (BV) can vary [12]. Second, two different storage techniques, cryopreservation (CP) or cold storage (CS), are applied [14]. Thereby, CP refers to blood storage between $-65--140^{\circ} \mathrm{C}$, while CS refers to blood storage at $4{ }^{\circ} \mathrm{C}$, which is equivalent to refrigerator level $[14,15]$. The storage techniques will be explained in more detail in Section 3.1, when they are discussed. The storage duration might differ between the storage techniques since CS stored blood is durable for 35-42 days, while CP allows a blood storage for up to ten years $[12,16]$.

The blood preparation and storage methods of the blood have not been compared so far. This appears to be a research gap, because the restoration of RBC mass after sampling is an important factor for the effect size of $\mathrm{ABD}$. In addition to that, the storage technique might influence the quality of the re-infused RBC. It is widely agreed that an increase in $\mathrm{RBC}$ and a corresponding increase of the hemoglobin mass $(\mathrm{Hb})$ is the major determinant of ABD-related performance enhancements [3,12]. ABD might affect RBC structure and/or function, which might affect exercise performance $[17,18]$, but the precise mechanisms related to the different $\mathrm{ABD}$ methods remain to be investigated Third, according to current literature, the amount of re-infused blood after storage varies between 135 and $>900 \mathrm{~mL}$, but a possible dose response relation of re-transfused blood and performance parameters was not described so far $[19,20]$.

The aim of this review was to analyze and compare the current literature regarding reported differences in the storage conditions and the storage duration applied during $\mathrm{ABD}$ and to assess the provided changes in exercise performance in relation to the study design. This review also aimed to direct the focus on RBC changes caused by the ABD techniques. This information may provide new starting points for anti-doping advocates in the development of $\mathrm{ABD}$ detection techniques.

\section{Method}

A systematic search protocol was constructed that followed the PRISMA guidelines for systematic reviews to ensure the reproducibility of this systematic literature search [21]. This procedure is also recommended by the MDPI [22]. The research process is presented in a flow diagram (Figure 1) inspired by the PRISMA 2009 Flow-Diagram [21]. However, since no meta-analysis was conducted, the final step of the PRISMA 2009 Flow Diagram "Studies included in quantitative synthesis" was not carried out.

The primary aim, and thus end point, of this review was to evaluate described effects of blood re-transfusion on exercise performance with a special focus on the described storage technique and storage duration and to relate these changes to possible changes in the red blood cell system. 


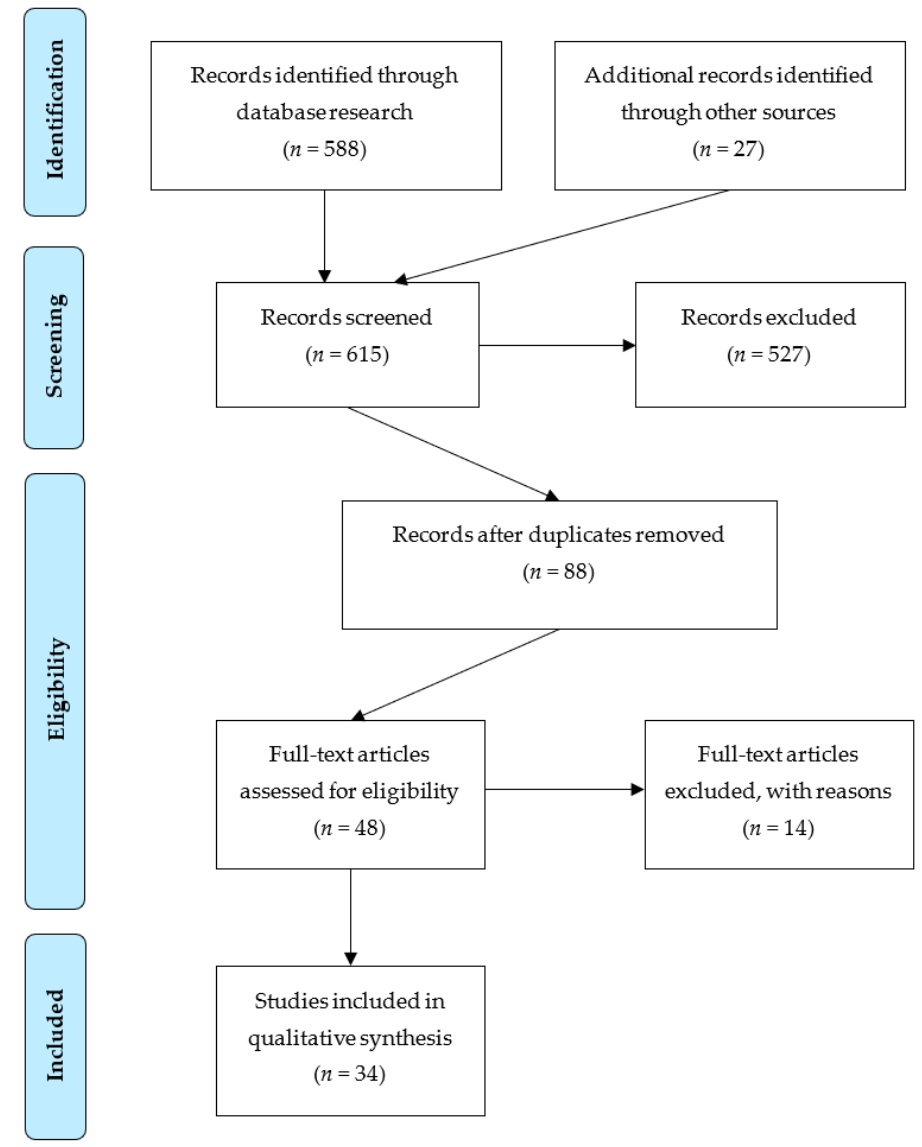

Figure 1. Research process. Flow diagram inspired by PRISMA 2009 Flow Diagram [21].

To select articles, that are eligible for the reviewing process, a full text search was conducted. Applied keywords included "autologous blood doping" and "autologous blood transfusion" combined with either "sport", "exercise", or "performance"-using the fixed Boolean operators of each database. The used databases included PubMed, BioMedsearch, Spolit, Web of Science, EBSCOhost, and ProQuest. The inclusion criteria for articles of these databases were: (1) articles in peer reviewed journals, (2) the reference to a sport context, (3) articles investigating blood parameters and/or exercise performance, and (4) the accessibility of the full text. No restrictions concerning the publication dates were made. Articles that fulfilled the inclusion criteria in title and abstract were taken into the record. The first step in the research process led to $n=588$ articles. Additionally, a forward and a backward search was conducted for the identified articles. The search engine Google Scholar (scholar.google.com) was used for these searches. The forward backward search resulted in additional $n=27$ articles, thus a total amount of $n=615$ articles was identified for the screening process. During the screening process, $n=527$ articles were removed as they did not meet the review's criteria. The screening resulted in $n=88$ articles for further research. After removing duplicates, a full text examination of the remaining $n=48$ articles was conducted to identify the articles qualified for the qualitative analysis. During this step, review articles were removed too, since they do not present primary data (they were included in the search as they are part of the literature and are eligible sources to identify applicable articles). The final search process resulted in $n=34$ articles.

The analysis of the selected articles focused on two major aspects. First, the blood storage technique applied (CS or $\mathrm{CP}$ ) were described and compared regarding possible differing effects of CS and $\mathrm{CP}$ on changes of performance and related blood parameters. Second, the time interval between blood donation and re-infusion was analyzed. The effect of improved performance after re-transfusion of stored blood relates to the restoration of initial RBC mass and the additional benefit of extra blood volume after the re-transfusion. 
The articles were analyzed whether or not a full recovery of RBCs might be reasonable, the minimal period between donation and re-infusion to gain an effect on exercise performance and if the length of the period affects the ABD outcome.

\section{Results and Discussion}

ABD is applied in order to increase RBC mass and thus oxygen transport capacity of the blood and to improve exercise performance [23]. ABD not only increases oxygen delivery to the working muscle but also increases the heat tolerance of the athletes [24]. The International Olympic Committee (IOC) banned blood boosting after the 1984 Olympics [25]. Flow cytometry methods for membrane surface double population of antigens may reveal the homologous blood transfusion approach [26-28] but autologous blood transfusion is not detected by this method. Thus, new approaches are designed as indirect markers for blood doping, including total $\mathrm{Hb}$ mass measurements, or to test for the excretion of metabolites of bag plasticizers in the urine. Another attempt to detect autologous transfusions is the Athlete Biological Passport (ABP) [29,30] which contains the longitudinal monitoring of biologic measures to identify patterns that might be related to ABD and the evaluation of such abnormal patterns by a panel of experts. These parameters might be affected by the storage duration and storage technique via an effect on RBC. Parameters include $\mathrm{RBC}$ count, $\mathrm{Hb}$ concentration, hematocrit, mean cellular $\mathrm{Hb}$ concentration, mean cellular volume, and the reticulocyte percentage [31,32]. Further, OFF-Hr score $([\mathrm{Hb}]-60 \sqrt{ }$ Ret\%, normal range: 85-95 [7]) and abnormal blood profile score (ABPS)—which are calculated parameters and are also mainly dependent on RBC related parameters-are also monitored in the ABP $[33,34]$. This strategy might involve several drawbacks, including differences in threshold values between the different sports associations and the difficult interpretation of hematological parameters because of wide inter-individual differences [35]. Recent data suggest that the RBC function itself might be affected by the ABD process and that the measurements of certain RBC parameters, for example RBC deformability, might in the future provide a promising attempt to detect ABD [17,36]. Still, valid detection methods are unavailable at present, but might benefit from the knowledge on the real effects of performance improvements after $\mathrm{ABD}$ and the relation to changes in $\mathrm{RBC}$ or $\mathrm{Hb}$ concentration.

As mentioned earlier, ABD is capable of improving the muscular $\mathrm{O}_{2}$ supply system and thus endurance exercise performance. Several studies analyzed within this review reported either improvements in the $\mathrm{VO}_{2 \max }$ or $\mathrm{VO}_{2 \text { peak }}$, or augmentation of the time to exhaustion test (TTE) or the time trial test (TT). $\mathrm{VO}_{2 \max }$ refers to the maximum possible $\mathrm{O}_{2}$ availability $\left(\mathrm{VO}_{2}\right)$ for the working muscles. $\mathrm{VO}_{2}$ peak is provided if the monitored oxygen uptake values do not flatten during the exercise test but still increase at time of termination of the exercise test $[37,38]$. Thus, both tests are considered to be the most adequate to examine a subject's endurance capacity $[37,39]$. Because $\mathrm{VO}_{2 m a x}$ and $\mathrm{VO}_{2 \text { peak }}$ are often used incorrectly as synonyms [40], this review will not differentiate between theses parameters. The TTE measures the time a subject is able to perform a standardized exercise protocol [41]. The TT quantifies the time a subject needs to finish a standardized task, or the standardized work a subject is able to complete within a fixed time frame [42]. The findings of improvements in endurance exercise due to ABD were in line with the current literature [3,12,19].

The wide range of exercise improvements is probably related to differences in the implied ABD method. Different storage technique and varying storage durations appear to be a moderator to the ABD outcome. Therefore, the following section aims to outline differences in the applied ABD_concerning storage duration and storage techniqueand how these affect performance and performance related blood parameters. Therefore, Sections 3.1 and 3.2 each discuss a part of the ABD method. To gain an optimal understanding, Table 1 serves as an overview of the applied methods and important parameters of the selected articles. 
Table 1. Overview of analyzed original articles related to effects of blood storage techniques and storage duration on performance outcome in autologous blood doping (ABD).

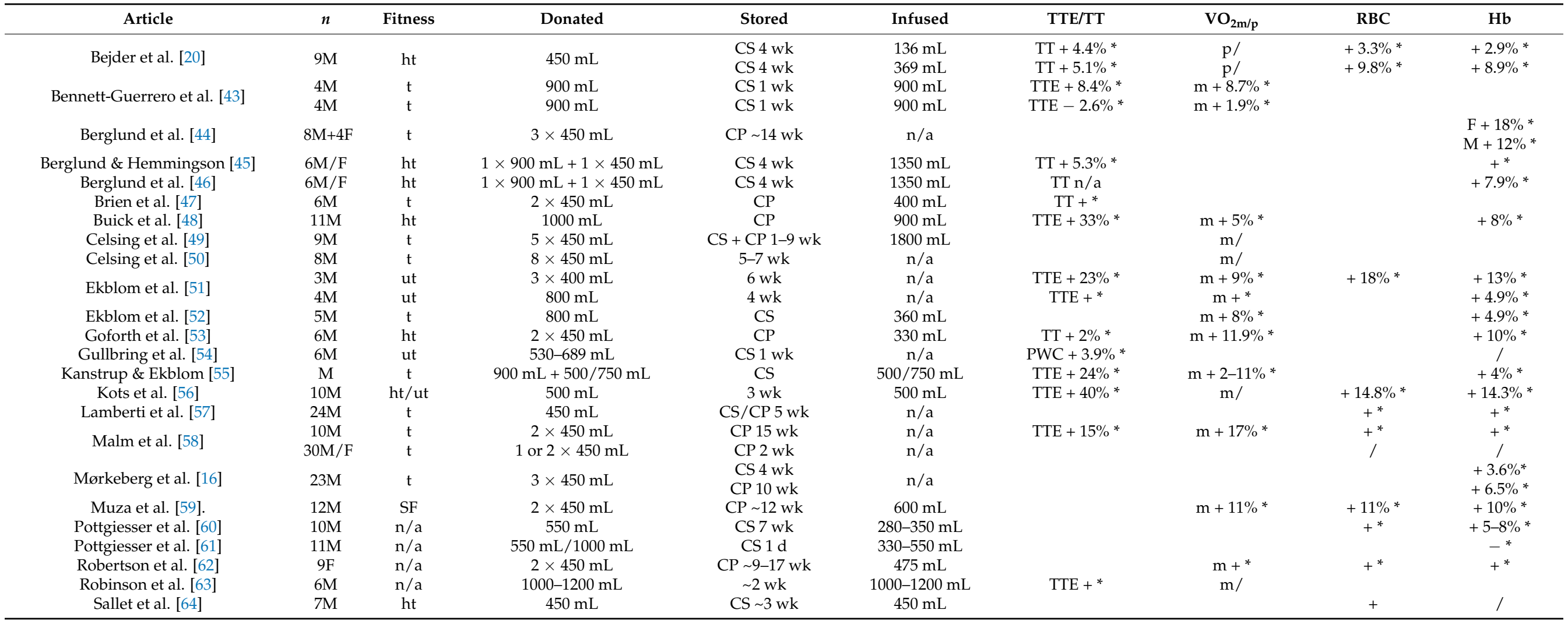


Table 1. Cont.

\begin{tabular}{|c|c|c|c|c|c|c|c|c|c|}
\hline Article & $n$ & Fitness & Donated & Stored & Infused & TTE/TT & $\mathrm{VO}_{2 \mathrm{~m} / \mathrm{p}}$ & RBC & $\mathrm{Hb}$ \\
\hline Sawka et al. [65] & $30 \mathrm{M}$ & $\mathrm{n} / \mathrm{a}$ & $450 \mathrm{~mL}$ & $\mathrm{CP}$ & $600 \mathrm{~mL}$ & & $m+*$ & & $+10 \% *$ \\
\hline \multirow[t]{2}{*}{ Sawka et al. [66] } & $9 \mathrm{M}$ & $t$ & $2 \times 450 \mathrm{~mL}$ & CP 6 wk & $600 \mathrm{~mL}$ & & $m+11 \%$ * & $+11 \%$ * & $+10 \% *$ \\
\hline & $4 \mathrm{M}$ & ht & & & $450 \mathrm{~mL}$ & & $\mathrm{~m} /$ & & $+^{*}$ \\
\hline \multirow{2}{*}{ Spriet et al. [67] } & $4 \mathrm{M}$ & ht & $1 \times 900 \mathrm{~mL}+1 \times 450 \mathrm{~mL}$ & $\mathrm{CP} \sim 10 \mathrm{wk}$ & $900 \mathrm{~mL}$ & & $\mathrm{~m}+7.5-10.7 \%$ * & & $+^{*}$ \\
\hline & $4 \mathrm{M}$ & ht & & & $1350 \mathrm{~mL}$ & & $m+10-13.3 \%$ * & & $+^{*}$ \\
\hline Thomson et al. [68] & $4 \mathrm{M}$ & $t$ & $2 \times 500 \mathrm{~mL}$ & $\mathrm{CP} \sim 12 \mathrm{wk}$ & $\mathrm{n} / \mathrm{a}$ & $\mathrm{TT}+10 \% *$ & $\mathrm{~m}+*$ & & $+^{*}$ \\
\hline Thomson et al. [69] & $4 \mathrm{M}$ & ut & $2 \times 500 \mathrm{~mL}$ & $\mathrm{CP}$ & $\mathrm{n} / \mathrm{a}$ & $\mathrm{TT}+*$ & $\mathrm{~m}+*$ & & $+*$ \\
\hline Turner et al. [70] & $7 \mathrm{M}$ & $\mathrm{n} / \mathrm{a}$ & $2 \times 450 \mathrm{~mL}$ & $\mathrm{CP}$ & $\mathrm{n} / \mathrm{a}$ & $\mathrm{TT}+5.3 \%$ * & $\mathrm{m}+*$ & & $+3.9 \%$ * \\
\hline Williams et al. [71] & $\begin{array}{l}5 \mathrm{M} \\
5 \mathrm{M}\end{array}$ & $\begin{array}{l}\text { ht } \\
\text { ht }\end{array}$ & $500 \mathrm{~mL}$ & CS $3 w k$ & $500 \mathrm{~mL}$ & TTE/ & & & \\
\hline Williams et al. [72] & $16 \mathrm{M}$ & ht & $460 \mathrm{~mL}$ & CP 3 wk & $460 \mathrm{~mL}$ & TTE/ & & / & / \\
\hline Williams et al. [73] & $12 \mathrm{M}$ & ht & $2 \times 460 \mathrm{~mL}$ & $\mathrm{CP} \sim 9 \mathrm{wk}$ & $920 \mathrm{~mL}$ & $\mathrm{TT}+*$ & & $+*$ & $+*$ \\
\hline Ziegler et al. [74] & $8 \mathrm{M}$ & $\mathrm{n} / \mathrm{a}$ & $450 \mathrm{~mL}$ & $\sim 4 \mathrm{wk}$ & $245 \mathrm{~mL}$ & $\mathrm{TT}+4.6 \% *$ & $\mathrm{p}+4.8 \% *$ & $t^{*}$ & $+^{*}$ \\
\hline
\end{tabular}

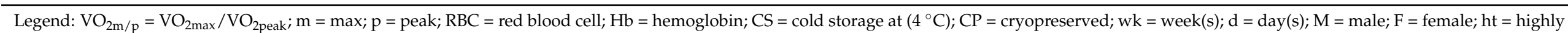

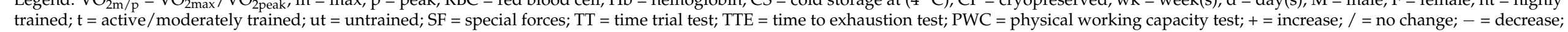

$*=$ significant; $X . X \%=$ change in $\% ; n / a=$ not available. 


\subsection{Blood Storage Techniques}

The performed literature analysis suggested two different storage techniques applied during ABD: $\mathrm{CP}$ and CS.

ABD involves sampling of 1-4 units of blood (1 unit corresponds to $450 \mathrm{~mL}$ blood) 8-12 weeks before competition to allow recovery of the RBC mass back to pre-donation level. The blood is centrifuged, the plasma is usually transferred back to the donor or discarded, and the RBC are stored and re-infused into the donor/athlete 1-7 days before a competition [12]. During CS, RBC were stored in the storage solution SAGM (saline, adenine, glucose, mannitol) at $4{ }^{\circ} \mathrm{C}$, but several published articles suggest that the quality of $\mathrm{RBC}$ decreases during storage at $4{ }^{\circ} \mathrm{C}$ and that re-infusion of long term stored $\mathrm{RBC}$ might be deleterious [75,76]. These deleterious effects are reduced when RBC are cryopreserved [36]. During $\mathrm{CP}$, blood is sampled in common blood bags and anticoagulated using CPDA-1 solution (citrate, phosphate, dextrose, and adenine). The blood bags are automatically processed to separate the RBC. Glycerol is added as cryoprotectant $[15,77]$ and the RBC are either fast frozen $\left(>100{ }^{\circ} \mathrm{C} / \mathrm{min}\right)$ and stored below $-140{ }^{\circ} \mathrm{C}$ or slowly frozen $\left(\sim 1-3^{\circ} \mathrm{C} / \mathrm{min}\right)$ and stored between -65 and $-80^{\circ} \mathrm{C}[15,77]$. The hypothermia of the $\mathrm{CP}$ stops the aging of RBC and thereby prevents the maturity of the cells [36], while the $4{ }^{\circ} \mathrm{C}$ of CS only slows the aging but does not prevent the cells death [78,79]. Cryopreserved RBC are thawed when needed by an automated cell processor device [12]. Differences between CS and CP include the allowed storage time and the occurrence of the so-called storage lesions [12]. Maximum storage time of CS ranges between 35 and 42 days, while cryopreserved RBC are allowed to be stored up to 10 years $[12,14]$. Further aspects of the storage durations will be addressed in Section 3.2. Blood storage is associated with the loss of RBC. According to recent literature, the RBC loss in CS is about $6 \%$ per week, while the loss of RBC during CP is stated to be about $15 \%$ in total due to the processing for the CP storage [14].

From the 34 selected articles, 11 studies used CS while 15 articles used CP, another three articles used both techniques and five articles did not mention their storage technique. Improved performance parameters and/or increased associated blood parameters were presented by nine out of $11(9 / 11)$ CS studies, 14/15 CP studies, and 2/3 CS+CP studies. Thus, it seems plausible that improvements of the performance might be achieved by both storage techniques $[20,48,53]$. It was not possible to argue whether there is a clear detectable relation of the performance increases and a specific storage technique because the selected studies showed high variations in their study designs. Only Celsing and co-workers [49], Lamberti and colleagues [57], and Mørkeberg and associates [16] applied both storage techniques at the same time. But the study by Celsing et al. [49] mixed both storage techniques within one experiment and thus a comparison between the techniques was not possible. Furthermore, Lamberti and co-workers did not differentiate between $\mathrm{CP}$ and CS in their results and did not present any data to compare the storage techniques. In contrast, Mørkeberg and colleagues differentiated between $\mathrm{Hb}$ level changes in CP and CS. The authors detected a 3.6\% increase in $\mathrm{Hb}$ content after re-infusion of blood stored under CS conditions and an increase in $\mathrm{Hb}$ level of $6.5 \%$ after the re-infusion of blood stored under CP conditions (both groups were re-infused with "all three bags" [16] (p. 287). This might suggest a higher increase in $\mathrm{Hb}$ concentration by $\mathrm{CP}$. However, the study design implemented a time frame of 4 weeks between blood sampling and re-infusion for the CS group and a period of 10 weeks for the $\mathrm{CP}$ group. Because this difference might affect the recovery of $\mathrm{RBC}$ amount and $\mathrm{Hb}$ mass in vivo, the results were not suitable to compare both storage techniques.

The data suggested that possible differences between CS and CP in performance and related blood parameters appeared to be less understood but relevant because the storage condition and the known quality changes potentially affected the results described. Further, the quality of the stored $\mathrm{RBC}$ was affected by so called storage lesion, which differs between CS and CP. The precise findings of storage lesions will not be addressed in this review and were described in detail elsewhere [80,81]. However, some aspects will be described 
herein. RBC lose their deformability, an important parameter to ensure nutrient and oxygen supply in the microcirculation, during CS [82], while RBC deformability of cryopreserved RBC appears not to be negatively affected [36]. The decrease in RBC deformability in CS might be associated to RBC senescence, which includes not only a reduction in cell volume, externalization of phosphatidylserine, and reduction in CD47 [83], but also a loss in 2,-3-DPG and ATP and reduction in nitric oxide bioavailability. During senescence in CS, cell volume loss stiffens the RBC and leads to reduction in RBC deformability [84]. Thus, old RBC are prone to hemolysis or phagocytosis during the circulation and might reduce the outcome during re-infusion [75]. Stopped or highly reduced RBC ageing during $\mathrm{CP}$ storage is thus of advantage to preserve the quality of the cells. Further, the deglycerolization procedure applied during the thawing of $\mathrm{CP}$ cells and mainly responsible for the RBC loss during CP is suggested to destroy mainly old RBC [85]. Hence, the average $\mathrm{RBC}$ population age is reduced in $\mathrm{CP}$ in comparison to CS. This further positively affects the RBC deformability, density, size, and $\mathrm{O}_{2}$ affinity [18,84], which leads to an increased diffusion capacity and an improved muscular $\mathrm{O}_{2}$ supply $[18,86]$. Since there appear to be several differences in the RBC count, $\mathrm{Hb}$ content concerning the different storage techniques, it appears to be relevant to investigate these differences directly.

Furthermore, it is noteworthy that the majority of the articles published in the last 20 years either implied CS $[19,20,43,60,61,64]$ or do not comment on the storage technique [87]. This appears to be contradictory to the actual applied ABD techniques in professional sports $[11,88]$. Because the different storage techniques in ABD probably lead to different blood adaptations and possibly different enhancements of the endurance performance, there is a need for future studies. These should focus on the effects of CP on functional blood parameters in relation to endurance capacity. This knowledge will allow to identify parameters affected by this procedure in order to develop new detection methods.

\subsection{Blood Storage Duration}

The second variable affecting the outcome of the ABD method is the storage duration. This refers to the time period between the blood donation from a subject and the blood re-infusion back to the initial donor. The importance of this phase during ABD is due to the fact that the increase in RBC mass after re-infusion evolves not from the re-infusion itself, but from the interplay between the recovery of RBC mass in vivo after sampling [89,90]caused by an artificially created momentary anemia [91-93] — and the following re-infusion of additional RBC [3,12]. A decrease in circulating RBC after blood sampling increases erythropoietin (EPO) expression in the kidney and release, which stimulates erythropoiesis in the bone marrow [91]. The production of RBC starts with a pluripotent hematopoietic stem cell $[89,90]$. Among others, EPO is the key driver for of the differentiation of the progenitor cells into colony forming units-erythroid, proerythroblasts, and erythroblasts [94,95]. Erythropoiesis lasts approximately five to nine days. Reticulocytes are then released into the circulation to mature into RBC [90].

The RBC restoration of the RBC mass to pre-donation level [96] is essential for the performance enhancement caused by ABD. An additional aspect of the increase in erythropoiesis rate after blood sampling is a probable change in the RBC quality. The neoformation of young RBC reduces the average age of the circulating RBC pool [17]. This reduction in RBC age results from the interplay of an increased RBC production accompanied by a normal RBC mortality rate [17,97]. Young RBC are more deformable compared to other $\mathrm{RBC}$ and are suggested to show increased oxygen transport capacity $[84,86]$. Thus, rejuvenation of circulating RBC might improve ABD effect size [18]. However, further studies are needed to support this relation.

Although the restoration period appears to be a central element in ABD, only two articles tested the effect of different storage durations on exercise performance [51,58]. However, one of the two studies [51] tested differences in sampled blood volume in parallel and thus, the results of this article were less suitable for a comparison of storage durations. The second study [58] tested the exercise performance of the candidates after re-transfusion 
of the blood after a storage duration of 15 weeks and 2 weeks, respectively. After a storage duration of 15 weeks, TTE increased by $15 \%, \mathrm{VO}_{2 \max }$ by $17 \%$, and also $\mathrm{RBC}$ count and $\mathrm{Hb}$ were significantly increased. In contrast, after 2 weeks of storage, $\mathrm{Hb}$ level and RBC count were not significantly altered. A performance test was not carried out [58]. These data indicate that the storage duration should be long enough to allow the blood parameters to reach the initial level prior to re-transfusion of the stored blood in order to significantly affect exercise performance [58].

According to current literature, recovery of the RBC content after donation of $500 \mathrm{~mL}$ of whole blood is estimated to last 59 days $[60,74,98]$. Referring to the selected articles in this review, only Robertson and co-workers [62] respect this recovery period. However, studies reporting a shorter period between blood donation and re-infusion present improvements in endurance performance and related blood parameters [20,51,74]. In general, the selected articles present a wide range of time frames between blood donation and re-infusion of 1 day up to 17 weeks [61,62]. The analysis of these articles revealed that the minimal recovery period needed to establish significant improvements in the endurance performance or relevant blood parameters appeared to be 4 weeks. Nine out of thirty-four articles described a storage time of less than 4 weeks (1 day to 3 weeks). However, only four of these articles detected significant improvements in TTE of up to 40\% [43,56,63], physical working capacity (PWC) of 3.9\% [54], Hb level of $14.3 \%$, and RBC of $14.8 \%$ [56]. These findings suggest that this rather short recovery period might be sufficient for the tested subjects to at least recover a part of their RBC mass after sampling and that this might be sufficient to improve the performance. However, the recovery process of RBC is rather complex and mainly depends on an increased erythropoiesis, which might take one week to produce additional RBC [99]. Therefore, full recovery of the whole RBC mass during a recovery time of three weeks seems unlikely. Further, three of the four mentioned articles $[43,54,63]$ sampled a blood volume $>500 \mathrm{~mL}$, which might need even more time to recover than the reported 59 days. The three articles that reported improvements in exercise performance after a recovery time of less than three weeks showed some limitation in the study design. The authors scheduled the baseline test after the blood sampling, shortly before the re-infusion $[43,56,63]$. Thus, baseline values of the performance parameters, but also $\mathrm{RBC}$ count and level of $\mathrm{Hb}$, might be artificially reduced because of the blood loss. The increase in performance parameters likely express the effect of a restoration rather than an "on top" effect that is intended. Thus, a central element of the ABD mechanismthe need of RBC mass recovery-was disregarded. In contrast to that, Gullbring and co-workers [54] - the fourth article detecting an increase in endurance performance with storage durations less than four weeks-performed the baseline measurements before the blood sampling. PWC performance significantly increased by 3.9\%. in the post re-infusion test. However, it cannot be ruled out that this result might also be related to an adaptation to the test protocol because the authors scheduled several tests between sampling and re-transfusion as well.

Furthermore, the test performed one day pre re-infusion presents a similar PWC performance compared to the test $1 \mathrm{~h}$ post re-infusion. In addition, no significant increase in the $\mathrm{Hb}$ level was detected by the authors. This missing $\mathrm{Hb}$ increase presents a further indicator that the performance increase might be rather related to muscular adaptation than to changes in the subjects' blood parameters. In contrast to the aforementioned articles, five of the articles analyzed herein with a storage duration of less than 3 weeks did not report any significant improvements in the tested performance—or relevant blood parameters. Furthermore, all articles with a storage duration of 4 weeks or more present significant changes in either the endurance performance, relevant blood parameters, or in both.

In summary, articles that described improvements in performance parameters after blood re-infusion but had storage durations less than four weeks also presented methodical weaknesses. Articles with storage durations less than four weeks and a reasonable study design regarding the exercise tests presented no significant improvements, but all articles with a storage time of 4 weeks or more, which might be needed to fully recover RBC mass, 
report improvements in performance and/or in related blood parameters including RBC or $\mathrm{Hb}$. Thus, it was concluded that a minimum of four weeks is needed as RBC restoration time for any ABD effect on performance parameters. Future anti-blood doping studies should consider this information during the development of detection methods.

\section{Limitations}

The present article provides a better understanding of two key factors affecting the exercise performance related to ABD. Nevertheless, the small number of key words comprised in the applied search string might represent a limitation of the present review. For instance, in some articles the re-transfusion of RBC is also referred to as induced erythrocythemia. However, this term was not included in the conducted search, because it would also lead to articles not associated to autologous blood doping. Also, the literature search of this review only focused on peer reviewed original articles and thus excludes alternative sources such as proceedings, conference papers, and books [100].

\section{Conclusions}

This review revealed that the storage technique applied, and the storage duration adhered are two major factors that affect the endurance performance capacity in the context of autologous blood doping (ABD). The results of the literature review indicated that cold storage (CS) shows disadvantages compared to cryopreservation (CP) with regard to possible storage time. Also, the quality of RBC highly reduced during CS, which might lead to adverse effects for the exercise capacity. The review indicated that $\mathrm{CP}$ might be favored in the ABD procedure. The literature analyzed herein further revealed that a large proportion of published articles reported storage durations that might be insufficient to allow the restoration of initial RBC mass. This might in part explain the absence of positive effects of re-infused RBC on exercise parameters, but might also lead to the assumption that the reported positive effects of $\mathrm{ABD}$ on exercise performance might at least in part result from other influencing variables.

In order to understand the physiological changes in the RBC system during ABD, which is indispensable to develop ABD detection techniques, it might be of relevance to focus on three topics in future research: (1) investigation of the influence of CP on the ABD outcome because this might be the most used in current doping cases, (2) investigation of the influence of a proper restoration time on ABD outcome, (3) investigation of the changes in functional and structural RBC parameters during ABD.

Author Contributions: Conceptualization, B.S. and M.G.; methodology, B.S.; investigation, B.S.; writing-original draft preparation, B.S. and M.G.; visualization, B.S.; supervision, M.G.; project administration, M.G. All authors have read and agreed to the published version of the manuscript.

Funding: This research received funding by the HIFF of the German Sports University Cologne.

Data Availability Statement: Not Applicable.

Conflicts of Interest: The authors declare no conflict of interest.

\section{References}

1. Peters, C.; Schulz, T.; Oberhoffer, R.; Michna, H. Doping und Dopingprävention: Kenntnisse, einstellungen und erwartungen von Athleten und trainern Doping and Doping Prevention: Knowledge, Attitudes and Expectations of Athletes and Coaches. Dtsch. Z. Sportmed. 2009, 60, 73-78.

2. Chorbok, D. Zur Strafbarkeit nach dem Anti-Doping-Gesetz; Herbert Utz Verlag: Munich, Germany, 2017 ; Volume 116.

3. Mørkeberg, J. Detection of autologous blood transfusions in athletes: A historical perspective. Transfus. Med. Rev. 2012, 26, 199-208. [CrossRef] [PubMed]

4. Birkland, K.I.; Hemmersbach, P. The future of doping control in athletes. Sports Med. 1999, 28, 25-33. [CrossRef] [PubMed]

5. Armstrong, J.D.; Reilly, T. Blood Boosting and Sport. In Drugs in Sport; Mottram, D., Ed.; Routleg: London, UK, 2005; Volume 4, pp. 207-227.

6. Bassett, J.D.R.; Howley, E.T. Blood doping: Then and now. A narrative review of the history, science and efficacy of blood doping in elite sport. Med. Sci. Sports Exerc. 2000, 32, 70-84. [CrossRef] [PubMed]

7. Jelkmann, W. Features of Blood Doping: Merkmale von Blutdoping. Dtsch. Z. Sportmed. 2016, 67, 255-262. [CrossRef] 
8. Pottgiesser, T.; Echteler, T.; Sottas, P.E.; Umhau, M.; Schumacher, Y.O. Hemoglobin mass and biological passport for the detection of autologous blood doping. Med. Sci. Sports Exerc. 2012, 44, 835. [CrossRef]

9. Marina, S. Operation Aderlass: “Ein Eindeutiges Licht auf die Dopingsituation”. Available online: https://www.deutschlandfunk. de/operation-aderlass-ein-eindeutiges-licht-auf-die.1346.de.html?dram:article_id=485211 (accessed on 27 October 2020).

10. Fiedler, M. Operation Aderlass: Angeklagter Arzt legt in Dopingprozess Umfassendes Geständnis ab. Available online: https://www.spiegel.de/sport/operation-aderlass-arzt-legt-in-doping-prozess-umfassendes-gestaendnis-ab-a-9be6fdba-9e2 0-4970-bf30-2614a76eda7e (accessed on 22 October 2020).

11. Behr, M. Grenzwertig: Aus dem Leben eines Dopingdealers; Riva Sportverlag: Wien, Austria, 2011.

12. Leigh-Smith, S. Blood boosting. Br. J. Sports Med. 2004, 38, 99-101. [CrossRef]

13. Zorzoli, M. Blood monitoring in antidoping setting. In Recent Advances in Doping Analysis: Sport und Buch; Schänzer, W., Geyer, H., Gotzmann, A., Mareck, M., Eds.; Sportverlag Strauß: Köln, Germany, 2005; pp. 255-264.

14. Jones, M.; Pedoe, D.T. Blood doping-A literature review. Br. J. Sports Med. 1989, 23, 84-88. [CrossRef]

15. Lagerberg, J.W. Cryopreservation of red blood cells. In Cryopreservation and Freeze-Drying Protocols; Wolkers, W.F., Oldenhof, H., Eds.; Springer: New York, NY, USA, 2015; pp. 353-367.

16. Mørkeberg, J.; Belhage, B.; Ashenden, M.; Bornø, A.; Sharpe, K.; Dziegiel, M.H.; Damsgaard, R. Screening for autologous blood transfusions. Int. J. Sports Med. 2009, 30, 285-292. [CrossRef]

17. Bizjak, D.A.; Grolle, A.; Urena, J.A.N.; Bloch, W.; Deitenbeck, R.; Grau, M. Monitoring of RBC rheology after cryopreservation to detect autologous blood doping in vivo? A pilot study. Clin. Hemorheol. Microcirc. 2020, 1-13, preprint. [CrossRef]

18. Böning, D.; Maassen, N.; Pries, A. The hematocrit paradox-How does blood doping really work? Int. J. Sports Med. 2011, 32, 242-246. [CrossRef] [PubMed]

19. Solheim, S.A.; Bejder, J.; Breenfeldt Andersen, A.; Mørkeberg, J.; Nordsborg, N.B. Autologous Blood Transfusion Enhances Exercise Performance-Strength of the Evidence and Physiological Mechanisms. Sports Med. Open 2019, 5, 30-41. [CrossRef] [PubMed]

20. Bejder, J.; Breenfeldt, A.A.; Solheim, S.A.; Gybel-Brask, M.; Secher, N.H.; Johansson, P.I.; Nordsborg, N.B. Time Trial Performance is Sensitive to Low-Volume Autologous Blood Transfusion. Med. Sci. Sports Exerc. 2019, 51, 692-700. [CrossRef] [PubMed]

21. Moher, D.; Liberati, A.; Tetzlaff, J.; Altman, D.G.; Prisma, G. Preferred reporting items for systematic reviews and meta-analyses: The PRISMA statement. PLoS ONE 2009, 6. [CrossRef]

22. MDPI. Publishing Standards and Guidelines. Available online: https://www.mdpi.com/editorial_process\#standards (accessed on 25 December 2020).

23. Lippi, G.; Franchini, M.; Salvagno, G.L.; Guidi, G.C. Biochemistry, physiology, and complications of blood doping: Facts and speculation. Crit. Rev. Clin. Lab. Sci. 2006, 43, 349-391. [CrossRef]

24. Dowling, P. Erythropoietin a review. Sports Health 1990, 8, 30-32.

25. Berglund, B. Development of techniques for the detection of blood doping in sport. Sports Med. 1988, 5, 127-135. [CrossRef]

26. Nelson, M.; Ashend, M.; Langsahw, M.; Popp, H. Detection of homologous blood transfusion by flow cytometry: A deterrent against blood doping. Haematologica 2002, 87, 881-882. [CrossRef]

27. Nelson, M.; Popp, H.; Sharpe, K.; Ashend, M. Proof of homologous blood transfusion through quantification of blood group antigens. Haematologica 2003, 88, 1284-1295.

28. Voss, S.C.; Thevis, M.; Schinkothe, T.; Schänzer, W. Detection of homologous blood transfusion. Int. J. Sports Med. 2007, 28, 633-637. [CrossRef]

29. Cazzola, M. A global strategy for prevention and detection of blood doping with erythropoietin and related drugs. Haematologica 2000, 85, 561-563. [PubMed]

30. Malcovati, L.; Pascutto, C.; Cazzola, M. Hematologic passport for athletes competing in endurance sports: A feasibility study. Haematologica 2003, 88, 570-581. [PubMed]

31. Gore, C.J.; Parisotto, R.; Ashenden, M.J.; Stray-Gundersen, J.; Sharpe, K.; Hopkins, W.; Emslie, K.R.; Howe, C.; Trout, G.J.; Kazlauskas, R.; et al. Second-generation blood tests to detect erythropoietin abuse by athletes. Haematologica 2003, 88, 333-344. [CrossRef] [PubMed]

32. WADA. Athlete Biological Passport Operating Guidelines and Compilation of Required Elements. Volume 2.1. Available online: https://www.wada-ama.org/sites/default/files/resources/files/WADA_ABP_OperatingGuidelines_EN_2.1.pdf (accessed on 10 November 2020).

33. Sanchis-Gomar, F.; Pareja-Galeano, H.; Brioche, T.; Martinez-Bello, V.; Lippi, G. Altitude exposure in sports: The Athlete Biological Passport standpoint. Drug Test. Anal. 2004, 6, 190-193. [CrossRef]

34. Segura, J.; Minfort, N.; Ventura, R. Detection methods for autologous blood doping. Drug Test. Anal. 2012, 4, 876-881. [CrossRef]

35. Sottas, P.-E.; Robinson, N.; Saugy, M. The athlete's biological passport and indirect markers of blood doping. In Doping in Sports: Biochemical Principles, Effects and Analysis; Thieme, D., Hemmersbach, P., Eds.; Springer: Berlin, Germany, 2010; pp. 305-326.

36. Bizjak, D.A.; Jungen, P.; Bloch, W.; Grau, M. Cryopreservation of red blood cells: Effect on rheologic properties and associated metabolic and nitric oxide related parameters. Cryobiology 2018, 84, 59-68. [CrossRef]

37. Cade, W.T.; Bohnert, K.L.; Reeda, D.N.; Peterson, L.R.; Bittel, A.J.; Bashir, A.; Byrne, B.J.; Taylor, C.L. Peak oxygen uptake (VO2peak) across childhood, adolescence and young adulthood in Barth syndrome: Data from cross-sectional and longitudinal studies. PLoS ONE 2018, 13. [CrossRef] 
38. Hollmann, W.; Strüder, K.; Predel, H.-G.; Tagarakis, C. Kardiopulmonale Leistungsdiagnostik des Gesunden und Kranken; Schattauer: Stuttgart, Germany, 2006.

39. Huggett, D.L.; Connelly, D.M.; Overend, T.J. Maximal aerobic capacity testing of older adults: A critical review. J. Gerontol. Ser. A Biol. Sci. Med Sci. 2005, 60, 57-66. [CrossRef]

40. Green, S.; Askew, C. VO2peak is an acceptable estimate of cardiorespiratory fitness but not VO2max. J. Appl. Physiol. 2018, 125, 229-232. [CrossRef]

41. Nicolò, A.; Sacchetti, M.; Girardi, M.; McCormick, A.; Angius, L.; Bazzucchi, I.; Marcora, S.M. A comparison of different methods to analyse data collected during time-to-exhaustion tests. Sports Sci. Health 2019, 15, 667-679. [CrossRef]

42. Laursen, P.B.; Francis, G.T.; Abbiss, C.R.; Newton, M.J.; Nosaka, K. Reliability of time-to-exhaustion versus time-trial running tests in runners. Med. Sci. Sports Exerc. 2007, 39, 1374-1379. [CrossRef] [PubMed]

43. Bennett-Guerrero, E.; Lockhart, E.L.; Bandarenko, N.; Campbell, M.L.; Natoli, M.J.; Jamnik, V.K.; Carter, R.C.; Moon, R.E. A randomized controlled pilot study of $\mathrm{VO} 2$ max testing: A potential model for measuring relative in vivo efficacy of different red blood cell products. Transfusions 2017, 57, 630-636. [CrossRef] [PubMed]

44. Berglund, B.; Birgegård, G.; Wide, L.; Pihlstedt, P. Effects of blood transfusions on some hematological variables in endurance athletes. Med. Sci. Sports Exerc. 1989, 21, 637-642. [CrossRef] [PubMed]

45. Berglund, B.; Hemmingson, P. Effect of reinfusion of autologous blood on exercise performance in cross-country skiers. Int. J. Sports Med. 1987, 8, 231-233. [CrossRef] [PubMed]

46. Berglund, B.; Hemmingson, P.; Birgegård, G. Detection of autologous blood transfusions in cross-country skiers. Int. J. Sports Med. 1987, 8, 66-70. [CrossRef] [PubMed]

47. Brien, A.J.; Simon, T.L. The effects of red blood cell infusion on 10-km race time. JAMA 1987, 257, 2761-2765. [CrossRef]

48. Buick, F.J.; Gledhill, N.; Froese, A.B.; Spriet, L.; Meyers, E.C. Effect of induced erythrocythemia on aerobic work capacity. J. Appl. Physiol. 1980, 48, 636-642. [CrossRef]

49. Celsing, F.; Nystrom, J.; Pihlstedt, P.; Werner, B.; Ekblom, B. Effect of long-term anemia and retransfusion on central circulation during exercise. J. Appl. Physiol. 1986, 61, 1358-1362. [CrossRef]

50. Celsing, F.; Svedenhag, J.; Pihlstedt, P.; Ekblom, B. Effects of anaemia and stepwise-induced polycythaemia on maximal aerobic power in individuals with high and low haemoglobin concentrations. Acta Physiol. Scand. 1987, 129, 47-54. [CrossRef]

51. Ekblom, B.; Goldbarg, A.N.; Gullbring, B. Response to exercise after blood loss and reinfusion. J. Appl. Physiol. 1972, 33, 175-180. [CrossRef]

52. Ekblom, B.; Wilson, G.; Astrand, P.O. Central circulation during exercise after venesection and reinfusion of red blood cells. J. Appl. Physiol. 1976, 40, 379-383. [CrossRef] [PubMed]

53. Goforth, J.H.W.; Hodgdon, J.A.; Sucec, A.A.; Campbell, N.L.; Rasmussen, W.T. Effect of Induced Erythrocythemia on Aerobic Capacity, Ventilatory Threshold, and Run Performance; Naval Health Research Center: San Diego, CA, USA, 1999.

54. Gullbring, B.; Holmgren, A.; Sjöstrand, T.; Strandell, T. The effect of blood volume variations on the pulse rate in supine and upright positions and during exercise. Acta Physiol. Scand. 1960, 50, 62-71. [CrossRef] [PubMed]

55. Kanstrup, I.L.; Ekblom, B. Blood volume and hemoglobin concentration as determinants of maximal aerobic power. Med. Sci. Sports Exerc. 1984, 16, 256-262. [CrossRef] [PubMed]

56. Kots, Y.M.; Shcherba, M.M.; Kolker, Y.S.; Gorodetskii, V.D.; Sin, L.D. Experimental study of the relationship between the blood hemoglobin concentration and phyiscal aerobic working capacity. Hum. Physiol. 1978, 4, 43-49. [PubMed]

57. Lamberti, N.; Finotti, A.; Gasparello, J.; Lampronti, I.; Zambon, C.; Cosenza, L.C.; Fabbri, E.; Dalla Corte, F.; Govoni, M.; Reverberi, R.; et al. Changes in hemoglobin profile reflect autologous blood transfusion misuse in sports. Intern. Emerg. Med. 2018, 13, 517-526. [CrossRef] [PubMed]

58. Malm, C.B.; Khoo, N.S.; Granlund, I.; Lindstedt, E.; Hult, A. Autologous doping with cryo-preserved red blood cells-effects on physical performance and detection by multivariate statistics. PLoS ONE 2016, 11, e0156157. [CrossRef] [PubMed]

59. Muza, S.R.; Sawka, M.N.; Young, A.J.; Dennis, R.C.; Gonzalez, R.R. Elite Special Forces: Physiological Description and Ergogenic Influence of Blood Infusion. Aviat. Space Envon. Med. 1987, 58, 1001-1004.

60. Pottgiesser, T.; Specker, W.; Umhau, M.; Dickhuth, H.H.; Roecker, K.; Schumacher, Y.O. Recovery of hemoglobin mass after blood donation. Transfusion 2008, 48, 1390-1397. [CrossRef]

61. Pottgiesser, T.; Umhau, M.; Ahlgrim, C.; Ruthardt, S.; Roecker, K.; Schumacher, Y.O. Hb mass measurement suitable to screen for illicit autologous blood transfusions. Med. Sci. Sports Exerc. 2007, 39, 1748-1756. [CrossRef]

62. Robertson, R.J.; Gilcher, R.; Metz, K.F.; Caspersen, C.J.; Allison, T.G.; Abbott, R.A.; Skrinar, G.S.; Krause, R.J.; Nixon, P.A. Hemoglobin concentration and aerobic work capacity in women following induced erythrocythemia. J. Appl. Physiol. 1984, 57, 568-575. [CrossRef]

63. Robinson, B.F.; Epstein, S.E.; Kahler, R.L.; Braunwald, E. Circulatory effects of acute expansion of blood volume: Studies during maximal exercise and at rest. Circ. Res. 1966, 19, 26-32. [CrossRef]

64. Sallet, P.; Brunet-Guedj, E.; Mornex, R.; Baverel, G. Study of a new indirect method based on absolute norms of variation to detect autologous blood transfusion. Int. J. Hematol. 2008, 88, 362-368. [CrossRef] [PubMed]

65. Sawka, M.N.; Dennis, R.C.; Gonzalez, R.R.; Young, A.J.; Muza, S.R.; Martin, J.W.; Wenger, C.B.; Francesconi, R.P.; Pandolf, K.B.; Valeri, C.R. Influence of polycythemia on blood volume and thermoregulation during exercise-heat stress. J. Appl. Physiol. 1987, 62, 912-918. [CrossRef] [PubMed] 
66. Sawka, M.N.; Young, A.J.; Muza, S.R.; Gonzalez, R.R.; Pandolf, K.B. Erythrocyte reinfusion and maximal aerobic power: An examination of modifying factors. JAMA 1987, 257, 1496-1499. [CrossRef]

67. Spriet, L.L.; Gledhill, N.; Froese, A.B.; Wilkes, D.L. Effect of graded erythrocythemia on cardiovascular and metabolic responses to exercise. J. Appl. Physiol. 1986, 61, 1942-1948. [CrossRef]

68. Thomson, J.M.; Stone, J.A.; Ginsburg, A.D.; Hamilton, P. The effects of blood reinfusion during prolonged, heavy exercise. Canadian journal of applied sport sciences. J. Can. Des Sci. Appl. Au Sport 1983, 8, 72-78.

69. Thomson, J.M.; Stone, J.A.; Ginsburg, A.D.; Hamilton, P. $\mathrm{O}_{2}$ transport during exercise following blood reinfusion. J. Appl. Physiol. 1982, 53, 1213-1219. [CrossRef]

70. Turner, D.L.; Hoppeler, H.; Noti, C.; Gurtner, H.P.; Gerber, H.; Schena, F.; Ferretti, G. Limitations to VO2max in humans after blood retransfusion. Respir. Physiol. 1993, 92, 329-341. [CrossRef]

71. Williams, M.; Goodwin, A.; Perkins, R.; Bocrie, J. Effect of blood reinjection upon endurance capacity and heart rate. Med. Sci. Sports 1973, 5, 181-186. [CrossRef]

72. Williams, M.H.; Lindhjem, M.; Schuster, R. The effect of blood infusion upon endurance capacity and ratings of perceived exertion. Med. Sci. Sports 1978, 10, 113-118.

73. Williams, M.H.; Wesseldine, S.; Somma, T.; Schuster, R. The effect of induced erythrocythemia upon 5-mile treadmill run time. Med. Sci. Sports Exerc. 1981, 13, 169-175. [CrossRef] [PubMed]

74. Ziegler, A.K.; Grand, J.; Stangerup, I.; Nielsen, H.J.; Dela, F.; Magnussen, K.; Helge, J.W. Time course for the recovery of physical performance, blood hemoglobin, and ferritin content after blood donation. Transfusion 2015, 55, 898-905. [CrossRef] [PubMed]

75. Grau, M.; Friedrichs, P.; Krehan, S.; Koliamitra, C.; Suhr, F.; Bloch, W. Decrease in red blood cell deformability is associated with a reduction in RBC-NOS activation during storage. Clin Hemorheol. Microcirc. 2015, 60, 215-229. [CrossRef] [PubMed]

76. Wang, D.; Sum, J.; Solomon, S.B.; Klein, H.G.; Natanson, C. Transfusion of older stored blood and risk of death: A meta-analysis. Transfusion 2012, 52, 1184-1195. [CrossRef]

77. Stefanic, M.; Ward, K.; Tawfik, H.; Seemann, R.; Baulin, V.; Guo, Y.; Fleury, J.-B.; Drouet, C. Apatite nanoparticles strongly improve red blood cell cryopreservation by mediating trehalose delivery via enhanced membrane permeation. Biomaterials 2017, 140, 138-149. [CrossRef]

78. Hess, J.R. Measures of stored red blood cell quality. Vox Sang. 2014, 107, 1-9. [CrossRef]

79. Stoll, C.; Holovati, J.L.; Acker, J.P.; Wolkers, W.F. Synergistic effects of liposomes, trehalose, and hydroxyethyl starch for cryopreservation of human erythrocytes. Biotechnol. Prog. 2012, 28, 364-371. [CrossRef]

80. Kim-Shapiro, D.B.; Lee, J.; Gladwin, M.T. Storage lesion: Role of red blood cell breakdown. Transfusion 2011, 51, 844-851. [CrossRef]

81. Yoshida, T.; Prudent, M.; D'Alessandro, A. Red blood cell storage lesion: Causes and potential clinical consequences. Blood Transfus. 2019, 17, 27-52. [CrossRef]

82. Islamzada, E.; Meatthews, K.; Guo, Q.; Santoso, A.T.; Duffy, S.P.; Scott, M.D.; Ma, H. Deformability based sorting of stored red bloodcells reveals donor-dependent aging curves. R. Soc. Chem. 2020, 20, 226-235. [CrossRef]

83. Arias, C.F. How do red blood cells know when to die? R. Soc. Open Sci. 2017, 4, 160850. [CrossRef] [PubMed]

84. Bizjak, D.A.; Brinkmann, C.; Bloch, W.; Grau, M. Increase in red blood cell-nitric oxide synthase dependent nitric oxide production during red blood cell aging in health and disease: A study on age dependent changes of rheologic and enzymatic properties in red blood cells. PLoS ONE 2015, 10. [CrossRef] [PubMed]

85. Pallotta, V.; D'Amici, G.; D'Alessandro, A.; Rossetti, R.; Zolla, L. Red blood cell processing for cryopreservation: From fresh blood to deglycerolization. Blood Cells Mol. Dis. 2012, 48, 226-232. [CrossRef] [PubMed]

86. Smith, J.A.; Martin, D.T.; Telford, R.D.; Ballas, S.K. Greater erythrocyte deformability in world-class endurance athletes. Am. J. Physiol. Heart Circ. Physiol. 1999, 276, 2188-2193. [CrossRef] [PubMed]

87. Damsgaard, R.; Munch, T.; Mørkeberg, J.; Mortensen, S.P.; Gonzalez-Alonso, J. Effects of blood withdrawal and reinfusion on biomarkers of erythropoiesis in humans: Implications for anti-doping strategies. Haematologica 2006, 91, 1006-1008. [CrossRef] [PubMed]

88. Kornes, A. Verhafteter Doping-Arzt Hortete in Seiner Garage 40 Blutbeutel; Augsburger Allgemeine: Augsburg, Germany, 2019.

89. De Marées, H. Sportphysiologie (9. Aufl.); Sportverlag Strauß: Köln, Geramny, 2003.

90. Weineck, J. Sportbiologie (10. Aufl.); Spitta: Balingen, Geramny, 2010.

91. Goodnough, L.T.; Price, T.H.; Rudnick, S.; Soegiarso, R.W. Preoperative red cell production in patients undergoing aggressive autologous blood phlebotomy with and without erythropoietin therapy. Transfus. Apher. Sci. 1992, 32, 441-445. [CrossRef]

92. Goodnough, L.T.; Goodnough, L.T. The role of iron in erythropoiesis in the absence and presence of erythropoietin therapy. Nephrol. Dial. Transplant. 2002, 17, 14-18. [CrossRef]

93. Tasaki, T.; Ohto, H.; Hashimoto, C.; Abe, R.; Saitoh, A.; Kikuchi, S. Recombinant human erythropoietin for autologous blood donation: Effects on perioperative red-blood-cell and serum erythropoietin production. Lancet 1992, 339, 773-775. [CrossRef]

94. Spivak, J.L. The Mechanism of Action of Erythropoietin. Int. J. Cell Cloning 1986, 4, 139-166. [CrossRef]

95. Hattangadi, S.M.; Wong, P.; Zhang, L.; Flygare, J.; Lodish, H.F. From stem cell to red cell: Regulation of erythropoiesis at multiple levels bymultiple proteins, RNAs, and chromatin modifications. Am. Soc. Hematol. 2011, 118, 6258-6268. [CrossRef]

96. Dudrick, S.J.; O’Donnell, J.J.; Raleigh, D.P.; Matheny, R.G.; Unkel, S.P. Rapid restoration of red blood cell mass in severely anemic surgical patients who refuse transfusion. Arch. Surg. 1985, 120, 721-727. [CrossRef] [PubMed] 
97. Lorentz, A.; Jendrissek, A.; Eckardt, K.U.; Schipplick, M.; Osswald, P.M.; Kurtz, A. Serial immunoreactive erythropoietin levels in autologous blood donors. Transfusion 1991, 31, 650-654. [CrossRef] [PubMed]

98. Högler, W.; Mayer, W.; Messmer, C.; Eibl, G.; Innerhofer, P.; Schönitzer, D.; Nussbaumer, W. Prolonged iron depletion afterallogeneic 2-unit RBC apheresis. Transfusion 2001, 41, 602-605. [CrossRef] [PubMed]

99. Singh, A.K. Erythropoiesis: The Roles of Erythropoietin and Iron. In Textbook of Nephro-Endocrinology, 2nd ed.; Singh, A.K., Williams, G.H., Eds.; Academic Press: Cambridge, UK, 2018; pp. 207-215.

100. Webster, J.; Watson, R.T. Analyzing the past to prepare for the future: Writing a literature review. Mis Q. 2002, 26, xiii-xxiii. 